Joanna Bielecka-Prus

Uniwersytet Marii Curie-Skłodowskiej

https://doi.org/10.18778/1733-8069.9.2.05

\title{
Poczucie winy jako emocja społeczna. Analiza wybranych nurtów badawczych
}

Abstrakt Poczucie winy jest jedną z najczęściej wymienianych emocji o społecznych źródłach, jednakże wciąż jeszcze zbyt mało wiadomo na temat procesów tworzenia osobistego i zbiorowego poczucia winy. Celem tego artykułu jest uporządkowanie sposobów ujęcia tego problemu. W pierwszej części artykułu omówione zostaną problemy, jakie wiążą się z definiowaniem pojęcia „poczucie winy” oraz jego sklasyfikowaniem. Następnie omówione zostaną wybrane teorie socjologiczne, które mogą okazać się szczególnie przydatne do analizy tego zespołu emocji, a szczególnie społecznego procesu wzbudzania, podtrzymywania i zarządzania poczuciem winy. W ostatniej części przedstawione zostaną wyniki analizy wywiadów pogłębionych z młodzieżą niedostosowaną społecznie na temat sposobów przeżywania winy w ich osobistym życiu.

Słowa kluczowe socjologia emocji, poczucie winy, wstyd, niedostosowanie społeczne

oanna Bielecka-Prus, dr, adiunkt w Instytucie Socjologii UMCS. Jej zainteresowania badawcze koncentrują się wokół problematyki badań jakościowych i wykorzystywania tych metod w badaniach terenowych nad wykluczeniem społecznym, marginalizacją społeczną, obcością i tożsamością społeczną. Jest autorką książki Transmisja kultury w rodzinie i w szkole. Teoria Basila Bernsteina (2010).

\section{Dane adresowe autorki:}

Instytut Socjologii

Wydział Filozofii i Socjologii UMCS

ul. Langiewicza 6a, pokój 18

20-032 Lublin

e-mail: prus@pronet.lublin.pl chologowie coraz cześciej przyznaja, że poczucie winy należy do grupy emocji interpersonalnych czy społecznych (np. Baumeister, Stillwell, Heatherton 1994). Tym bardziej zatem należałoby się dokładniej przyjrzeć, w jaki sposób można tę emocję zdefiniować, jak powiązać ją z innymi emocjami interpersonalnymi oraz procesami społecznymi zachodzącymi w szerszej skali. Warto także zastanowić się nad kierunkami i metodologią prowadzonych dotąd badań nad poczuciem winy. Problemy te stanowią pierwszą część rozważań zawartych w tym artykule. W drugiej części, która ma charakter wstępnych badań rozpoznawczych, przedstawiono strategie językowe stosowane przez młodzież niedostosowaną społecznie w rozmowach na temat odczuwania winy. Ta część jest zarazem propozycją metodologiczną, którą można zastosować w badaniu wzorów odczuwania poczucia winy u przedstawicieli różnych światów społecznych.

\section{Poczucie winy jako kategoria analizy}

Motyw poczucia winy i zadośćuczynienia pojawia się w wielu utworach literackich, intryguje intensywnością przeżywania, prowadzącego niekiedy bohaterów do upadku czy samobójstwa, jak to było w przypadku Doriana Greya, Makbeta czy Stawrogina, ale także do odkupienia przez pokutę, czego przykładem jest Raskolnikow z powieści Fiodora Dostojewskiego. Czym jest zatem ta emocja, która motywuje do tak ekstremalnych działań? Słownik języka polskiego PWN definiuje winę $\mathrm{w}$ szeroki sposób: jest to „czyn naruszający normy postępowania (prawne, obyczajowe, moralne)". Poczucie winy jest ciężarem, który można zrzucić, ale także można nim kogoś obarczyć, jest zmazą, z której można się oczyścić, wyznać lub darować. Synonimami winy są: przewinienie, wykroczenie, występek i grzech.
Problem winy analizowany jest $\mathrm{w}$ pracach filozofów moralności, religioznawców, prawników, psychiatrów, ale także i psychologów, szczególnie o psychoanalitycznych proweniencjach. Tymczasem teologiczne, prawnicze czy psychologiczne rozumienie winy nie wyczerpuje możliwych aspektów badań tego przeżycia. Teologiczne rozważania ściśle łączą winę z grzechem, spowiedzią i pokutą. Prawnicy zajmują się czynami niedozwolonym $\mathrm{w}$ systemie prawnym, pomijając pojawiające się lub niewystępujące po transgresji uczucia, bowiem wystarczającą przesłanką do orzekania o winie jest wadliwe ukształtowanie się woli sprawcy. Jedynie usprawiedliwiona nieświadomość, wykluczająca intencjonalność złamania norm prawnych jest czynnikiem blokującym postępowanie karne (Buchała, Zoll 1998). Jeśli natomiast przyjrzymy się winie z perspektywy socjologii moralności, to jest ona "przekroczeniem imperatywu moralnego" (Lazarus 1991: 122 [tłum. własne]). Pojawia się, gdy działająca jednostka naruszy obowiązujący w danym społeczeństwie i zinternalizowany przez nia system normatywny. Konieczne jest spełnienie tych dwóch warunków, bowiem przekroczenie norm, które mają wyłącznie charakter przymusu zewnętrznego, narzuconego przez ośrodki władzy nieuprawomocnionej, nie pociąga za sobą poczucia winy. Nie pojawi się ono także w sytuacji, gdy obowiązujące normy nie zostały zinternalizowane przez jednostkę (por. Mariański 1989).

Shweder i in. (1997) dzielą normy na 3 kategorie:

1. Chroniące prawa jednostki (np. własność prywatna, zdrowie).

2. Chroniące porządek społeczny (hierarchię społeczną, własność społeczną).

3. Chroniące porządek boski, sfere sacrum. 
Badania nad związkiem między emocjami a łamaniem wyróżnionych powyżej norm społecznych pokazały, że osoby łamiące prawa jednostki odczuwają poczucie winy, wstyd pojawia się w stosunku do osób łamiących porządek społeczny, a wstręt wobec występków przeciwko sacrum (Prinz 2005). Przedstawiciel psychiatrii humanistycznej, Antoni Kępiński (1992), wiąże poczucie winy z lękiem sumienia. Działania podejmowane przez jednostki są oceniane przez układ samokontroli, czyli system kar i nagród: nagrodą jest dobre samopoczucie i pozytywny wizerunek własny, karą zaś zła samoocena i związany z nią spadek nastroju i poczucie winy. Układ ten jest tworzony w wyniku interakcji ze społecznym otoczeniem, które poddaje ocenie działania jednostek ze względu na przyjęte $\mathrm{w}$ danym środowisku kulturowym normy i wartości.

Jednakże transgresja moralna nie wyjaśnia przypadków pojawienia się poczucia winy, gdy naruszenie norm nie nastąpiło. Istotna jest także jakość relacji łącząca jednostkę z innymi ludźmi, bowiem poczucie winy jest ściśle powiązane ze społecznym wymiarem życia ludzkiego. Tak jak grzech narusza relację między Bogiem a człowiekiem (Ricoeur 1991), wina narusza więzi łączące człowieka ze społecznością. Odczuwana jest, gdy jednostka nie zaspokoiła potrzeb innych lub uczyniła innym krzywdę - rzeczywistą lub wyobrażoną - i grozi jej wykluczenie społeczne (Baumeister, Stillwell, Heatherton 1994; Clark, Fitness, Brissette 2003). „Poczucie winy jest [...] naszym najdelikatniejszym i zarazem najsilniejszym łącznikiem z ludzką wspólnotą" (Kępiński 1979: 131). Wiąże się ze zdolnością jednostki do empatii, stawiania się $\mathrm{w}$ roli innych i pojawia się, gdy wyobrażamy sobie, że inni doznali z naszego powodu jakiegoś cierpienia, straty (Tangney,
Dearing 2002). Intensywność odczuwania poczucia winy zależy od typu relacji, jaka wiąże jednostkę z osobami pokrzywdzonymi: im silniejsza więź, tym poczucie winy jest głębsze. Dlatego też pojawia się najczęściej $\mathrm{w}$ bliskich relacjach, na przykład w rodzinie (Baumeister, Bushman 2008) i jest potwierdzeniem, że zależy nam na drugiej osobie. Troska o podtrzymywanie więzi może wyjaśniać częste przypadki pojawiania się poczucia winy u ofiar przemocy domowej, a także u osób, które wykazują wysoki poziom empatii. Poczucie winy może pojawić się także wtedy, gdy jednostka sama nie uczyniła nic złego, ale dostrzegła, że inn $\mathrm{w}$ jej otoczeniu cierpieli w większym stopniu niż ona sama. „Winę ocalonych” zauważono u osób którym udało się przeżyć obozy koncentracyjne, Holokaust czy bombardowanie miast (Shiota, Kalat 2007; Baumeister, Bushman 2008).

Poczucie winy związane jest także z poczuciem odpowiedzialności za swoje czyny. Aby poczuć się winnym, trzeba uznać się za podmiot sprawczy, a nie osobę, której coś się w życiu przydarzyło (Wierzbicka 1999). A zatem, im większa nasza odpowiedzialność, tym większe może być poczucie winy (Bourion 2005). Jednakże istotne jest tu subiektywnie zdefiniowane poczucie odpowiedzialności, a nie realny związek między czynem a krzywdą.

Wina jest zatem przeżyciem subiektywnym i wewnętrznym. Warunkiem jej pojawienia się jest zdolność podmiotu do samorefleksji (Caplovitz, Barrett 1995; Stets 2006). „Poczucie winy to świadomość, że jesteśmy obwinieni i postawieni przed wewnętrznym trybunałem [...] wina to samoobserwacja, samooskarżenie przez rozdwojoną świadomość" (Ricoeur 1991: 265). Istotne jest, że wynik tej oceny zależy od tego, $w$ jaki sposób oceniający ustali źródło sprawstwa oraz intencje: czy na zewnątrz, w świecie społecznym (atrybucja zewnętrzna), czy wewnątrz, jako podmiot sprawczy (atrybucja wewnętrzna), czy cała jaźń podlega ocenie (ogólna samoatrybucja), czy jedynie pewien fragment jaźni, czy wyodrębniona sekwencja działań jednostki.

Reasumując, poczucie winy pojawia się, gdy nastąpiła transgresja moralna $\mathrm{i} / \mathrm{lub}$ istnieje niebezpieczeństwo naruszenia istniejących więzi społecznych (z osobami bliskimi, znaczącymi lub uogólnionym innym), jednostka ma poczucie sprawstwa (rzeczywiste lub domniemane) i zdolność do samorefleksji.

\section{Typologia poczucia winy}

Poczucie winy nie poddaje się łatwo zabiegom typologicznym. Nie jest pewne, czy jest zlokalizowane w strukturach mózgowych, czy jest zjawiskiem kulturowym (Turner, Stets 2009), co odzwierciedla toczony na bardziej ogólnym poziomie spór między stanowiskiem naturalistycznym (zakładającym istnienie uniwersalnych emocji, uwarunkowanych cechami gatunkowymi, a niekiedy także ponadgatunkowymi) i kulturowym (emocje są skontekstualizowanym historycznie konstruktem społecznym)². Niektórzy przyznają, że poczucie winy mogą odczuwać nie tylko ludzie, ale także i zwierzęta, szczególnie ssaki naczelne oraz psy (Lazarus 1991). Oznaczałoby to, że emocja ta jest uwarunkowana biologicznie, dlatego też poczucie winy jest przez niektórych autorów włączone do grupy emocji pierwotnych (np. Emde 1984). Inni z kolei klasyfikowali je jako emocje powstającą na bazie emocji pierwotnych, na przykład radości i strachu (por. Plutchik 1991) lub smutku i rozczarowania wobec samego siebie oraz strachu przed ${ }^{2}$ Perspektywy te laccza się w takich subdyscyplinach, jak neu-
rosocjologia (neurosociology) i spoleczna neurobiologia (social rosocjologia
neuroscience). konsekwencjami (Turner, Stets 2009). Niektórzy zaś podtrzymują, że jest emocją wyuczoną na podstawie pierwotnej emocji strachu przed karą (Kemper 1987). Jednakże nawet zwolennikom biologicznych uwarunkowań poczucia winy nie jest łatwo powiązać przeżywaną emocję z reakcjami cielesnymi, chociaż niektórzy badacze (np. Summers-Effler 2004) zauważają, że negatywne emocje, które sa poddawane różnym strategiom obronnym, moga prowadzić do depresji, schorzeń psychosomatycznych czy nawet samobójstwa (Turner, Stets 2009)³. Inni badacze wskazują na zewnętrzne przejawy poczucia winy, takie jak: odwracanie wzroku, unikanie patrzenia w oczy rozmówcy (Laird 2007) jednakże nie są one somatyczne $\mathrm{w}$ takim stopniu, jak na przykład strach czy złość. Być może też dlatego zwolennicy biologicznego podłoża emocji niewiele miejsca $\mathrm{w}$ swoich rozważaniach poświęcają poczuciu winy, które nie pasuje do ogólnego schematu wyjaśniającego genezę ludzkich emocji. Inne typologie można spotkać w nurcie kulturowych badań nad emocjami. Mówi się o winie indywidualnej, dotyczącej jednostki oraz kolektywnej, obejmującej jakieś zbiorowości (np. Gilbert 2002). Typologie budowane są także w oparciu o kategorie osób doświadczających winy, na przykład: ofiar przestępstw, ocalonych z katastrofy czy zagłady, dewiantów, osób pozostawiających kogoś (wina separacyjna) czy jednostek popełniających przestępstwa lub wykroczenia. Inni badacze klasyfikują poczucie winy w zależności od sytuacji, w jakiej się pojawia: poczucie winy realne, wirtualne (związane z sytuacją wyobrażoną), dokonaniowe

${ }^{3}$ Nie należy mylić z poczuciem winy reakcji fizycznych badanych przez wariograf, który pomaga w ustaleniu sprawców przestępstw. Reakcje te są wynikiem pobudzenia (np. wzrost cisnienia krwi), ktore może mieć rożne żodła, zupełni poniezważ od dokonanego czynu niezgodnego z prawem, 
(związane z osiągnięciem jakiegoś dobra czy statusu) (por. Hoffman 2000) oraz uwarunkowań tych przejawów (np. wina zinternalizowana, pojawiająca się bez względu na zagrożenie karą i wina zeksternalizowana - występująca jedynie w obliczu takiego zagrożenia (por. Biaggio 1969).

\section{Poczucie winy a inne emocje}

Wiele teorii analizuje poczucie winy, wiążąc je z innymi emocjami, przede wszystkim lękiem, wstydem i współczuciem. Dyskusje te mają ważne implikacje metodologiczne, bowiem wyraźniej definiują przedmiot badań.

Lęk spowodowany jest antycypacją kary, która grozi za złamanie norm społecznych, jednakże jest przeżywany w sposób znacznie bardziej intensywny i ma podłoże egocentryczne, wskazywać może na słabą internalizację sytemu aksjonormatywnego i pojawia się zamiast poczucia winy (Ranschburg 1980). Inni badacze twierdza, że poczuciu winy towarzyszy lęk, który jest lękiem separacyjnym, lękiem przed utartą miłości, akceptacji czy więzi z otoczeniem społecznym. Plutchik (1991) uważa, że poczucie winy rodzi się ze wzajemnego oddziaływania przyjemności i strachu. Przyjemność płynie $\mathrm{z}$ transgresji, przekraczania niedozwolonych granic $\mathrm{w}$ poszukiwaniu przyjemności płynących z konsumpcji „owocu zakazanego", strach pojawia się przed ewentualną karą.

Wiele miejsca $\mathrm{w}$ analizach poświęca się na analizy porównawcze wstydu i poczucia winy jako stanów, które różną się od siebie znacząco, mimo wspólnego powiązania z negatywną samoocena. Psycholog June P. Tangney uważa, że zarówno wstyd, jak i poczucie winy związane są z negatywną samooceną, jednakże poczucie winy różni się od wstydu tym, że w pierwszym przypadku negatywnej ocenie poddana jest cała działająca jednostka, natomiast $\mathrm{w}$ drugim - jedynie konkretne działanie lub seria działań krzywdzących innych (Tangney, Dearing 2002). Mówiąc krótko, wstyd odnosi się do osoby, poczucie winy do jej konkretnych działań (Lewis 1971). Niektórzy badacze uważają, że wstyd jest wykroczeniem przeciwko wartościom, wina natomiast przeciwko normom społecznym (Teroni, Deonna 2008), jednakże dyskusyjne jest dokonywanie takiego „rozszczepienia” nomicznego systemu aksjonormatywnego. Jeszcze inni badacze twierdzą, że emocje te związane są z różnym typem norm społecznych. Wstyd pojawia się, gdy naruszone są normy obyczajowe, poczucie winy zaś jest skutkiem pogwałcenia podstawowych norm moralnych i autorytetu (Solomon 2007). Pojawiają się także opinie, że wina jest bardziej intensywnie odczuwanym wstydem (Kristjánsson 2010), choć teza ta jest krytykowana przez innych badaczy (np. Turner 2002). Niektórzy z kolei twierdzą, że poczucie winy jest konsekwencją silnie zinternalizowanych norm moralnych, wstyd natomiast wiąże się z obawami przed negatywną oceną innych, faktycznymi lub antycypowanymi negatywnymi sankcjami społecznymi. Inne są skutki odczuwania tych emocji. Uczucie wstydu powoduje chęć ucieczki, ukrycia się, natomiast poczucie winy: przeprosiny czy inne działania naprawcze lub wypieranie (Solomon 2007). Jak dowodzą badania eksperymentalne (Tangney i in. 1998), wstyd częściej związany jest $\mathrm{z}$ wrogością i agresją skierowaną na innych, motywuje jednostkę do poprawy własnego wizerunku w oczach innych, wina natomiast skłania jednostkę do zachowania zgodnego ze standardami moralnymi, jest uwewnętrznioną kontrolą społeczną, sprawnie funkcjonująca, nawet gdy inni członkowie społeczności nie są obecni.
Interesujący jest związek, jaki zachodzi między współczuciem a poczuciem winy. Z jednej strony, jak twierdzi Candance Clark (zob. Turner, Stets 2009), osoby zasługujące na współczucie to osoby, które nie ponoszą winy za swoje niedogodne położenie. $\mathrm{Z}$ drugiej strony, publiczne wyznanie winy przez czyniącego zło i wyrażenie skruchy budzi uczucie miłosierdzia, które jest formą współczucia i przebaczenia. Okazanie skruchy i przyznanie się jest zatem warunkiem wstępnym rozgrzeszenia.

Toczone dyskusje są dowodem na to, jak bardzo trudno jest wyodrębnić daną emocje z całego zespołu przeżyć, jakie jednostka może odczuwać w związku z konkretną sytuacją. Jest to problem, przed którym stoją nie tylko badacze emocji, ale również przeżywające te uczucia jednostki, które mogą mieć problemy z rozpoznaniem i nazwaniem własnych przeżyć.

\section{Poczucie winy $w$ teoriach emocji}

W badaniach nad emocjami można wyróżnić następujące podejścia teoretyczne, w których poczucie winy pojawia się jako przedmiot mniej lub bardziej pogłębionych analiz: podejście psychoanalityczne, kulturowe, symbolicznego interakcjonizmu, teorii wymiany i teorie strukturalne (Turner, Stets 2009). Jak już wspomniano, zwolennicy teorii biologicznych bardzo rzadko podejmują problematykę poczucia winy jako emocji, być może ze względu na to, że emocja ta $\mathrm{z}$ trudem poddaje się somatyzacji czy klasycznym badaniom neuropsychologicznym, dlatego pomięto je w poniższych rozważaniach.

W klasycznej psychoanalizie poczucie winy jest kategorią centralną i w pracach Zygmunta Freuda związane jest z tłumieniem kazirodczych pragnień seksualnych we wczesnym dzieciństwie i rozwo- jem superego. Zbyt głębokie lub częste przeżywanie poczucia winy nie jest $\mathrm{w}$ sposób konieczny powiązane z normatywną transgresja, ale wynika z niezdolności ego do godzenia popędów płynących z id z wymaganiami społecznymi zinternalizowanymi $\mathrm{w}$ superego i jest $\mathrm{w}$ klasycznej psychoanalizie traktowane jako stan chorobowy. Mimo iż klasyczna szkoła psychoanalityczna była wielokrotnie krytykowana, to trzeba przyznać, że jej najważniejszym osiągnięciem jest dostrzeżenie nieuświadomionego wymiaru poczucia winy. Aby radzić sobie z ciężarem winy, człowiek stosuje różnego typu mechanizmy obronne, które redukują dotkliwe napięcie (por. Kępiński 1992). Krytycy odrzucają teze o neurotycznym podłożu tej emocji. Na przykład Judith Butler (1997) uważa, że poczucie winy rodzi się w starciu dobra i zła, bowiem uczynione zło uaktywnia tkwiące $\mathrm{w}$ człowieku dobro, a pierwszą oznaką pobudzenia jest pojawienie się poczucia winy. Ten cały proces wymaga samorefleksji i czynnego udziału świadomości, która rozwija się w tych starciach, a zatem poczucie winy jest pozytywnym symptomem rozwoju podmiotowości.

Perspektywa kulturowa analizuje emocje w kontekście społecznym i zakłada, że zmieniają się one pod wpływem odmiennych warunków historycznych. Badania w tym nurcie prowadzone są $\mathrm{w}$ trzech kierunkach: pierwszy analizuje emocje z perspektywy funkcji, jakie pełnią one w życiu społecznym oraz wzajemnych wpływów zachodzących między procesami społecznymi a życiem emocjonalnym jednostek; drugi zaś ma charakter komparatystyczny i analizuje emocje w różnych kontekstach kulturowych; w trzecim zaś nurcie emocje są skontekstualizowanymi i regulowanymi praktykami społecznymi. W tej perspektywie mieszczą się klasyczne prace Emila Durkheima (2011) na temat funkcji 
uczuć moralnych w podtrzymywaniu porządku społecznego i spójności społecznej i badania Maxa Webera (1995) na temat związków między kapitalizmem a purytanizmem. Jednakże, gdy dla Durkheima poczucie winy mogło pchnąć jednostkę do samobójstwa, dla Webera było jednym z czynników napędzających kapitalistyczną gospodarkę. Niekiedy problematyka poczucia winy pojawia się na marginesie rozważań na temat zmiany społecznej. Jeśli przyjmiemy trzy stadia rozwoju moralności: moralność społeczeństw prymitywnych, moralność społeczeństw tradycyjnych i moralność społeczeństw pluralistycznych (Mariański 1990), to poczucie winy pojawia się $\mathrm{w}$ stadium społeczeństw tradycyjnych, gdy Ja odrywa się od struktur społecznych (por. Douglas 2004). W społeczeństwach pluralistycznych jest wiele współistniejących ze sobą imperatywów, często ze sobą sprzecznych, dlatego też jednostki mogą dokonywać kompilacji różnych systemów, niekiedy prowadzących do etycznego sytuacjonizmu i relatywizmu. Można zatem przypuszczać, że w społeczeństwach pluralistycznych funkcja samokontroli traci na znaczeniu (Jacyno 2007; Pawlik 2007).

Z kolei badania porównawcze prowadzone przez antropologów i psychologów wskazują na pewne różnice międzykulturowe. Badania prowadzone w 37 krajach (Wallbott, Scherer 1995) wykazały, że w kulturach kolektywistycznych (np. Ameryka Południowa, Grecja) uczucie wstydu było częściej odczuwane niż poczucie winy, natomiast w kulturach indywidualistycznych (np. USA, Szwecja) to poczucie winy było emocją dominującą. Wyróżnia się „społeczeństwa wstydu”, w których jednostka nie osiagga autonomii moralnej, jest podporządkowana społeczności, a unikanie złych czynów jest wynikiem lęku przed karą oraz „społeczeństwa winy", w którym autonomiczna jednostka unika złych czynów ze względu na szacunek dla uznanych przez siebie norm. Dychotomia tego podziału budzi wiele zastrzeżeń ze względu na zarzut etnocentryzmu, ponieważ $\mathrm{w}$ niektórych kulturach pozaeuropejskich nie ma dwóch odrębnych pojęć na określenie poczucia winy i wstydu, a zatem wyodrębnienie ich jest konstruktem kulturowym (Shiota, Kalat 2007).

Ważnym wątkiem w perspektywie kulturowej jest praca nad emocjami. Zdaniem Arlie R. Hochschild (2009) emocje należą do sytemu kulturowego, wraz z podzielaną społecznie wiedzą na temat rozpoznawania, ekspresji i klasyfikacji emocji własnych i cudzych. Reguły odczuwania określają, jakie emocje jednostka powinna przeżywać $\mathrm{w}$ danej sytuacji społecznej, natomiast reguły ekspresji wskazują, jak daną emocję można wyrazić w społecznie akceptowany sposób. Jednostki stale wykonuja pracę nad emocjami, która polega na określeniu, co $\mathrm{w}$ danej sytuacji należy odczuć, wzbudzeniu $\mathrm{w}$ sobie tego uczucia oraz jest związana $\mathrm{z}$ odpowiednią manipulacją swoim ciałem. Jednakże nie zawsze udaje się uzyskać harmonię miedzy tymi komponentami i jednostka zmuszona jest do ukrywania własnych uczuć lub ich odgrywania przed publicznością, okazywania emocji w sposób instrumentalny, aby osiągnąć określony cel. Mamy więc działania powierzchniowe, czyli odegranie uczucia przed publicznością bez emocjonalnego zaangażowania się oraz działania głębokie, które prowadzą do faktycznego przeżywania uczucia poprzez wzbudzenie go w sobie.

Symboliczny interakcjonizm zwraca uwagę na powstawanie emocji w interakcjach społecznych i ich rolę w kształtowaniu i podtrzymywaniu tożsamości społecznej, a co za tym idzie, także struktury spo- łecznej (Shott 1979; Stets 2006). Kluczowym pojęciem jest koncepcja siebie, która jest zespołem przekonań i emocji z nimi związanych dotyczących samego siebie. Rozwijając rozważania Charlesa Hortona Cooleya (1964), można zauważyć, że poczucie winy towarzyszy negatywnej samoocenie własnego postępowania z punktu widzenia znaczących innych (Baumeister, Stillwell, Heatherton 1994), braku potwierdzenia własnej tożsamości $\mathrm{w}$ interakcjach, jest emocją, która pojawia się wskutek rozbieżności między "ja rzeczywistym" (swoimi przekonaniem o faktycznie posiadanych cechach) a ,ja powinnościowym" (imperatywami postępowania) (Turner, Stets 2009).

Teorie wymiany analizują interakcje społeczne jako proces, w którym uczestnicy dążą do maksymalizacji zysków i minimalizowana strat. Wymianie tej towarzyszą emocje, które są pozytywne, gdy wymiana spełnia oczekiwania uczestników, negatywne zaś, gdy jedna ze stron doznaje rozczarowania. Ocena ta nie jest wyłącznie subiektywna, niektórzy teoretycy tego nurtu wprowadzają pojęcie wymiany sprawiedliwej, osadzając interakcje w kontekście normatywnym (np. Blau 1964). Sposób definiowania sprawiedliwej wymiany przez jednostki zależy od ich statusu społecznego i dostępu do władzy, słuszności alokacji dóbr i równości. Poczucie winy pojawia się, gdy zasady sprawiedliwej wymiany zostaną naruszone i jednostka zostanie nadmiernie nagrodzona lub gdy jednostka będzie przekonana o uzyskaniu nadmiernych nagród kosztem innych (Homans 1961; Hegtvedt 1990).

Teorie strukturalne badają związki, jakie zachodzą między strukturą społeczną (szczególnie relacjami władzy i statusu) oraz emocjami. Dla badań nad poczuciem winy przydatna może okazać się teoria władzy i statusu Roberta Thamma (por. Turner,
Stets 2009). Powstawanie emocji uwarunkowane jest oczekiwaniami jednostek co do właściwych zachowań $\mathrm{w}$ danej sytuacji oraz pozytywnymi i negatywnymi sankcjami. Poczucie winy pojawia się, gdy nie są spełnione oczekiwania wobec samego siebie, a mimo to jednostka otrzymuje nagrodę, natomiast partner interakcji nie, mimo iż spełnił oczekiwania innych. Emocja ta pojawia się także $\mathrm{w}$ relacjach $\mathrm{w}$ grupie, gdy jednostka nisko ocenia własne kompetencje, a swój wysoki status w grupie uznaje za bezzasadny, natomiast pozostali członkowie grupy nie mają co do tego zastrzeżeń.

Analizując dorobek poszczególnych perspektyw teoretycznych, można zauważyć, że poczucie winy jako emocja jedynie okazjonalnie pojawia się w pracach socjologicznych i przede wszystkim dotyczy winy kolektywnej. Trudno jest wyjaśnić ten stan rzeczy. Być może socjologowie przyjęli za prawdziwą tezę, że w społeczeństwach ponowoczesnych, pluralistycznych poczucie winy ma coraz mniejsze znaczenie i w związku z tym nie warto się nim zajmować. Psychologowie natomiast znacznie częściej prowadzą badania na temat uwarunkowań przeżywania poczucia winy, najczęściej jednak posługują się metodami eksperymentu i testów psychologicznych, których wyniki są analizowane statystycznie. Najczęściej stosowanym testem jest Test of Self-Conscious Affect (TOSCA), autorstwa June Tangney, który służy do badania poczucia winy i wstydu. Test ten składa się z sześciu podskal, które mierzą: skłonność do przeżywania wstydu, skłonność do przeżywania poczucia winy, atrybucje zewnętrzną, dystansowanie się od odpowiedzialności oraz dumę z siebie i dumę ze swojego zachowania. Innym często stosowanym narzędziem pomiaru jest skala GASP (Guilt and Shame Proneness) mierząca podatność 
na odczuwanie poczucia winy przez jednostki. Obie skale składają się z szeregu twierdzeń opisujących wyimaginowane sytuacje, w których badany określa, jakie jest prawdopodobieństwo, że zachowa się zgodnie z opisem. Z punktu widzenia socjologów obie techniki badawcze mają duże wady, ponieważ nie analizują rzeczywistych sytuacji społecznych przebiegających $\mathrm{w}$ naturalnym kontekście. Analiza emocji w kontekście procesów społecznych stanowi jedynie margines badań nad emocjami (według Agnety Fischer i Gerbena van Kleefa [2010] w latach 2008-2010 było to zaledwie $10 \%$ badań opublikowanych $\mathrm{w}$ renomowanym [IF 3.875] periodyku „Emotion"). Problematyczne jest także to, że najczęściej osoby badane to studenci, a trudno uznać tę grupę za reprezentatywną dla całego społeczeństwa.

Jednakże możliwe jest badanie emocji za pomocą innych technik badawczych. Szczególnie przydane mogą być wywiady, zwłaszcza wywiady narracyjne. Tymczasem $\mathrm{w}$ badaniach poczucia winy najczęściej analizuje się pisemne wypowiedzi badanych na temat ich przeszłych przeżyć związanych z poczuciem winy, które następnie analizuje się ilościowo, z perspektywy paradygmatu pozytywistycznego (np. Ferguson, Stegge, Damhuis 1991). Analizy takie nie pogłębiają problemu badawczego. Jedynie nielicznie badania wykorzystują możliwości, jakie daje analiza wywiadów pogłębionych (np. Benson 1985; Timor, Weiss 2008).

\section{Geneza i funkcje społeczne poczucia winy}

Socjologiczne i konstruktywistyczne podejścia krytykują naturalistyczne założenie o wrodzonych strukturach emocjonalnych i zakładają, że emocje są tworzone społecznie. Środowisko kulturowe defi- niuje, w jaki sposób emocje powinny być odczuwane i wyrażane, z jakimi sytuacjami społecznymi są powiązane, w jaki sposób, za pomocą kulturowo określonego słownika emocjonalnego, są opisywane.

W procesie socjalizacji poczucie winy kształtowane jest przez indukcję: okazywanie przez rodziców dezaprobaty dla krzywdzących działań dziecka poprzez zwracanie mu uwagi na negatywne odczucia ofiary. Rozwija się już na bardzo wczesnym etapie życia człowieka. Według Eriksona (Erikson 2000; Tillmann 2005) poczucie winy również pojawia się w trzeciej fazie rozwoju dziecka (około 4-5 roku życia) jako rezultat konfliktu między własnymi pragnieniami jednostki a otoczeniem społecznym. Pogodzenie tych sprzecznych tendencji prowadzi do ukształtowania odpowiedzialności za własne działania i akceptację norm społecznych dzięki powstającemu $\mathrm{w}$ tej fazie superego oraz identyfikacji z rodzicem tej samej płci. Niezmiernie ważne w kształtowaniu uczuć są emocjonalne kontakty z rodzicami, szczególnie z matką, rodzaj okazywanych przez nią emocji oraz sposoby ich ekspresji (Stets 2006). System komunikowania w rodzinie i związana z nim struktura ról wpływa na kształtowanie się emocji u dziecka. Zdaniem Bernsteina (1971) w rodzinach o słabo zaznaczonym podziale ról (rodziny personalne), w których komunikowanie rodziców z dzieckiem oparte jest na kodzie rozwiniętym, rodzice kontrolują zachowania dziecka manipulując jego poczuciem winy. Ważne są także metody wychowawcze, bowiem jeśli wychowanie dziecka w rodzinie opiera się na przemocy słownej lub fizycznej, z przewagą kar, autorytarnym stylem wychowania, empatia nie rozwija się i może nastąpić dystrofia rozwoju poczucia winy (Tangney 1991; Sheikh, Janoff-Bulman 2010). Istotny wpływ mają także media, a szczególnie gry komputerowe, które nasycone są scenami przemocy (TenHouten 2007). Badania pokazują, że częstość i intensywność odczuwania poczucia winy zależy od takich społecznych determinantów, jak płeć (kobiety częściej odczuwają winę) czy przekonania religijne (wzmacnia poczucie winy) (por. Stets, Carter 2012). Ważny jest także szerszy kontekst kulturowy, wzory władzy rodzicielskiej oraz wartość, jaką przypisuje się dziecku (por. Halberstadt, Lozada 2011).

Poczucie winy jest często opisywane przez popularne poradniki psychologiczne jako emocja negatywa, której należy się jak najszybciej pozbyć. Tymczasem wiele badań wskazuje, że emocja ta pełni ważne funkcje społeczne (Manstead 2010). Poczucie winy jest niezbędnym czynnikiem $\mathrm{w}$ rozwoju moralnym jednostki (Prinz 2005). Motywuje jednostkę do podejmowania działań na rzecz grupy, wzmacnia więzi społeczne łączące jednostkę z otoczeniem społecznym, chroni normy i wartości kulturowe, motywuje do udzielenia pomocy i podjęcia działań naprawczych, wzmacnia pozytywny wizerunek siebie po uzyskaniu przebaczenia. Może być wykorzystywane jako sposób wpływania na działania innych, jest sygnałem dla ofiary, że jest ważna dla łamiącego normę (Baumeister, Stillwell, Heatherton 1994). Antycypacja pojawienia się poczucia winy przez może powstrzymywać przed popełnieniem wykroczenia, a także skłania do brania odpowiedzialności za własne czyny, zapobiega aktom przemocy słownej i fizycznej, jeśli dziecko nauczone zostało odczuwania winy przez rozwój empatii (Tangney, Dearing 2002; Turner 2006). Okazywanie poczucia winy przywraca naruszony porządek normatywny i redukuje napięcia grupowe (Baumeister, Stillwell, Heatherton 1994).

June Tangney i Ronda Dearing (2002) uważają, że poczucie winy pełni bardziej doniosłą społecz- ną funkcje niż wstyd, ponieważ motywuje ludzie do pozytywnych działań, sprzyja naprawie zerwanych więzi społecznych, pobudza do współodczuwania cierpienia, okazywania empatii i refleksji nad własnym postępowaniem. Poczucie winy, w przeciwieństwie do uczucia wstydu, jest konstruktywne i wskazuje, że jednostce zależy na poprawie relacji $\mathrm{z}$ innymi (Baumeister, Stillwell, Heatherton 1994). Poczucie winy może być zatem swoistym „klejem”, który spaja relacje społeczne, nawet te niekorzystne z punktu widzenia jednostki, jak na przykład $w$ przypadkach relacji ofiary i kata. Jednakże zauważa się, że jeśli istnieje poczucie wspólnoty kulturowej z ofiarą, osoby odczuwające poczucie winy mają tendencję do działań pozytywnych, przełamywania podziałów. Postrzeganie ofiar jako „obcych” nie prowadzi do takich działań. Poczucie winy staje się wtedy jednym z komponentów budujących uprzedzenia.

Poczucie winy bierze udział w kontrolowaniu własnych działań przez przyjmowanie roli innego, który doznał szkody w wyniku działań jednostki. Bez emocji społecznych w procesie socjalizacji niemożliwe byłoby przyswojenie przez jednostkę norm społecznych, a także monitorowanie własnego postępowania zgodnie z normami społecznymi. Dlatego też psychopaci i socjopaci rzadko doświadczają poczucia winy (Stets 2006). Osoby z silnie rozwiniętym poczuciem winy są sumiennymi pracownikami, przestrzegającymi regulaminów, lojalnymi wobec przełożonych, zaangażowanymi $\mathrm{w}$ realizowanie zadań $\mathrm{w}$ firmie (Bourion 2005). Badania eksperymentalne pokazały, że ludzie odczuwający poczucie winy chętniej oferują pomoc (Baumeister, Bushman 2008), rzadziej wchodzą w konflikty z prawem i uzależniają się od substancji psychoaktywnych (Turner 2006), sa 
uczciwi w sprawach finansowych (Cohen, Panter, Turan 2012). Niektórzy badacze zauważają jednak, że wyparte ze świadomości poczucie winy może mieć negatywne konsekwencje: jednostka może dokonywać projekcji poczucia winy na innych, co w rezultacie prowadzi do wybuchów złości, tworzenia ideologii uprzedzeń, szczególnie $\mathrm{w}$ stosunku do grup czy obiektów, które są słabsze i nie potrafią się przeciwstawić przemocy. Nagromadzenie złych emocji w życiu społecznym może prowadzić do zmian społecznych w skali makrostrukturalnej. W przypadku emocji negatywnych mogą to być na przykład wojny, rewolucje czy akty ludobójstwa (Turner, Stets 2009).

Generalnie jednak uważa się, że poczucie winy jest emocją pełniąca pozytywne funkcje i jego brak w sytuacjach naruszających społeczny porządek normatywny jest postrzegany jako objaw patologii. Istnieją społeczne oczekiwania, że osoby popełniające wykroczenia normatywne, także wykroczenia prawne, będą przeżywały poczucie winy, które jest dowodem na to, że osoba ta nie jest zdemoralizowania społecznie. Tymczasem sytuacja nie jest taka prosta, bowiem część osób wchodzących w konflikty z prawem nie deklaruje, że taką emocję intensywnie przeżywa. Badania pokazują, że osoby takie stosują zróżnicowane strategie ochraniające poczucie własnej wartości, broniąc się przed etykietą przestępcy (Benson 1985). Z kolei kryminolodzy i pedagodzy uważają, że pojawienie się poczucia winy jest pozytywnym symptomem, wskazującym na skuteczność procesu resocjalizacji i zapobiegającym recydywie (Tangney, Stuewi, Mashek 2007). Nadawana przez społeczeństwo etykieta kryminalisty pcha przestępcę $w$ stronę subkultur dewiacyjnych, jeśli nie budzi w nim wstydu ani poczucia winy.
Aby temu zapobiec, zawstydzanie i wzbudzanie poczucia winy powinno mieć charakter reintegrujący, w którym nie występuje etykietyzacja całej osoby przestępcy, ale jedynie jego czynu. Czyniący zło, po uznaniu swojej winy i ewentualnym zadośćuczynieniu, jest ponownie włączany do społeczeństwa, a więź zostaje odbudowana (Braithwaithe 1989).

\section{Poczucie winy jako działanie powierzchniowe}

W drugiej szczęści artykułu przedstawię wyniki badań własnych, których celem było wstępne rozpoznanie sposobów definiowania i wzorów odczuwania poczucia winy oraz doświadczen biograficznych młodzieży, która weszła w konflikt z prawem. Badania przeprowadzone zostały z chłopcami w wieku 15-18 lat przebywającymi na terenie jednego z Młodzieżowych Ośrodków Wychowawczych (MOW) w województwie lubelskim. MOW to placówki resocjalizacyjne dla dzieci i młodzieży niedostosowanej społecznie, „wymagającej stosowania specjalnej organizacji nauki, metod pracy, wychowania i resocjalizacji" (Rozporządzenie Ministra Edukacji Narodowe z dnia 12 maja 2011). Zadaniem ośrodka jest eliminacja przyczyn i przejawów wszelkich form niedostosowania społecznego oraz „przygotowanie wychowanków do życia zgodnego z obowiązującymi normami społecznymi i prawnymi" (Rozporządzenie Ministra Edukacji Narodowej z dnia 12 maja 2011). Młodzież kierowana jest do ośrodków nakazem sądów rodzinnych (Ustawa o postępowaniu $w$ sprawach nieletnich $z$ dnia 26 października 1982). Placówki te mają charakter otwarty, jednakże ucieczka z nich może być podstawa do przeniesienia nieletniego do zamkniętego zakładu poprawczego. Ze względu na chęć uniknięcia skojarzeń badanych z zadaniami szkolnymi zdecydowałam się zastosować metodę wywiadu swobodnego. Przeprowadziłam dziesięć wywiadów indywidualnych z chłopcami, bez obecności wychowawców czy innych osób trzecich. Trzech $\mathrm{z}$ badanych umieszczono w MOW z powodu wielokrotnych kradzieży, pięciu z powodu pobić i aktów chuligaństwa, a dwóch z powodu kradzieży z rozbojem.

Rozmówcy z własnej woli udzielali wywiadów, nie stosowano wobec nich żadnych środków przymusu. Wywiady przeprowadzono $\mathrm{w}$ pokoju jednego z rozmówców, aby zwiększyć poczucie swobody wychowanków. Ze względu na drażliwość tematu starałam się unikać pytań sondujących, aby nie tworzyć atmosfery przesłuchania policyjnego. Trudne pytania, na przykład o sprawy rodzinne, zadawałam w sposób bardzo delikatny i ogólny, aby uniknąć bolesnych wspomnień. Starałam się w trakcie wywiadu utrzymywać postawę ciepłego zaangażowania, bardzo wyraźnie określiłam przed rozmową swoją rolę, wyjaśniając, że nie pracuję $\mathrm{w}$ instytucjach zajmujących się ściganiem przestępstw czy instytucjach resocjalizujących i przyszłam tutaj, aby „posłuchać ich historii”.

Rozmowy przebiegały $\mathrm{w}$ spokojnej atmosferze, choć zachowania niewerbalne i prozodyczne cechy wypowiedzi (np. nerwowe przebieranie palcami czy nogami przez moich rozmówców, mamrotanie, obniżanie tonu głosu poniżej granicy słyszalności) wskazywały, że sytuacja rozmowy była dla nich stresująca. Być może miały na to wpływ następujące czynniki: uruchomione mechanizmy wyparcia, brak zaufania do prowadzącego wywiad, trudności $\mathrm{w}$ formułowaniu dłuższych wypowiedzi ze względu na posługiwanie się kodem ograniczo- nym (Bernstein 1971), problemy z samorefleksja oraz brak kompetencji komunikacyjnej umożliwiającej wypowiadanie się na temat własnych odczuć. Trzeba podkreślić, że ujawnianie tego typu przeżyć może się nastoletnim chłopcom wydawać niewłaściwe i „niemęskie". Jak stwierdził jedne z badanych, to są tematy, o których się nie rozmawia z nikim. Podobnie zjawisko zaobserwowano wśród kobiet przebywających $\mathrm{w}$ więzieniu czy dzieci w wieku szkolnym. Badania wykazały, że ekspresja takich emocji, jak żal, smutek czy poczucie winy były poddane pracy emocjonalnej i tłumione, ponieważ były przejawem słabości charakteru (Greer 2002 Singer, Doornenbal 2006).

Zebrany materiał badawczy przeanalizowano, przyjmując konstruktywistyczną pespektywę, w której zakłada się, że emocje są wytworem poddającym się uwzorowaniom kulturowym i społecznym. W fazie projektowania badania zakładałam, że interesować mnie będzie sposób przeżywania i relacjonowania poczucia winy przez rozmówców oraz strategie zarządzania nimi. Jednakże $\mathrm{w}$ trakcie badań okazało się, że musiałam zrewidować moje pierwotne założenia, bowiem badani nie potrafili przywołać tego typu przeżyć w sytuacji transgresji norm. Podobne rezultaty uzyskano, badając przestępców zaawansowanych z dużym stażem działalności dewiacyjnej, którzy przyswoili normy subkultury i nie musieli posługiwać się technikami neutralizacji (Topalli 2006). Ponieważ wychodziłam z założenia, że badana grupa nie jest na etapie zaawansowanej dewiacji, zainteresowałam się problemem, który można sformułować następująco: dlaczego młodzież przebywająca $\mathrm{w}$ MOW $\mathrm{w}$ wywiadach nie przyznawała się do przeżywania poczucia winy $\mathrm{w}$ zawiąz$\mathrm{ku}$ z popełnionymi wykroczeniami? $\mathrm{W}$ analizach 
skupiłam się na następujących pytaniach badawczych: w jaki sposób badani definiują poczucie winy jako emocję? Czy i w jaki sposób neutralizują przeżywanie tej emocji w związku z popełnieniem czynów zabronionych? Jaką funkcję pełni inscenizacja tego przeżycia przed publicznością? Analiza prowadzona była na kilku poziomach: poznawczym (co badani wiedzą na temat poczucia winy?), interpretacyjnym (w jaki sposób badani interpretują swoje emocje przeżywane $\mathrm{w}$ przeszłości, widziane z punktu widzenia osoby osądzonej i poddanej degradacji społecznej?) oraz językowej (jakimi środkami językowymi posługują się rozmówcy?).

Analiza środków językowych stosowanych w narracjach o emocjach była przedmiotem badań nad emocjami (np. Kelers 2010). W badaniach tych zakładano, że mowa odzwierciedla zachodzące procesy psychiczne, a „referowanie emocji jest przyjęciem pewnej postawy w działaniach językowych" (Szumska 2000: 203). Emocje mogą pojawić się na poziomie słów i zdań (Kelers 2010):

- prozodycznym: rytm, ton głosu, akcent, intonacja, sposób wypowiadania wyrazów, modulacje, przeciąganie głosek i tym podobne, a także planowanie werbalne (wahania, niedokończenie wypowiedzi);

- leksykalnym: kategoryzacje, deskrypcje, wykrzykniki, czasowniki kazuatywne;

- syntaktycznym: krótkie pytania zadawane na końcu zdania (nie?, tak?, prawda?), hiperbole, wykrzykniki, pytania, porównania, metafory;

- retorycznym: strategie argumentacyjne, minimalizacja, neutralizacje, normalizacje.

\section{Definiowanie poczucia winy}

W pierwszej części wywiadu poproszono badanych o określenie, czym jest poczucie winy i kiedy się ono pojawia. Wychowankowie nie mieli na ogół problemów z podaniem prostej definicji poczucia winy, można było jednakże zauważyć, że często brakowało im słów na opisanie sytuacji czy stanów z własnego życia, co przejawiało się bardzo długimi chwilami milczenia oraz zwrotami typu: no ja nie wiem, jak to powiedzieć; możlizwe; nie zastanawiałem się nad tym; nie wiem, jak to ujać. Pojawiały się także długie pauzy, przerwanie wypowiedzi, zająknięcia. Oznacza to, że badani chłopcy mają problemy z odniesieniem wiedzy ogólnej do przeżyć spersonalizowanych, dotyczących własnej osoby. Może to świadczyć o nieświadomych mechanizmach wyparcia negatywnych przeżyć, o ile założymy, że takie istnieją (Kelers 2010)

Definicje formułowane przez badanych nie różniły się znacznie od definicji sformułowanych na gruncie teorii o emocjach, jednakże skupiały się one jedynie na relacji interpersonalnej, w której jedna z osób wyrządza krzywdę: to jest coś takiego, że jeśli ktoś coś źle zrobit dla innej osoby, i ta osoba odczuwa smutek, to jest poczucie winy. Osoba, która to zrobiła czuje się źle. Drugą stroną relacji może być każda istota żywa, ale przedmiot raczej nie, przedmiot można kupić, człowieka nie można. Osobę skrzywdzoną nazywano także poszkodowanym, co wskazuje na rekontekstualizację dyskursu prawniczego w wypowiedziach chłopców. Kategorie prawnicze, przyswojone prawdopodobnie wskutek częstych interakcji z organami ścigania, są stosowane jedynie wybiórczo, bo w wypowiedziach nie pojawia sie kategoria sprawcy, etykieta ta została odrzucona i wykluczona z rozmów. $\mathrm{W}$ jednej z wypowiedzi wyraźnie widać odwrócenie ról: skrzywdzony wy- mierzając karę, staje się agresorem, a winny ofiarą: jedna osoba ma poczucie winy, a druga chce wymierzyć karę. Wcześniej ten sam chłopiec stwierdził, że jak ktoś mi był coś zrobit, to ja bym dostawał agresji, a nie smutku. A zatem można być może mówić o samonapędzającm się procesie: wykroczenie-kara-agresja-wykroczenie. W wywiadzie z tym chłopcem (sprawca licznych pobić) wielokrotnie pojawiała się kategoria agresji, którą rozmówca często odczuwa w stosunku do innych: chodzi o to, że czuje nie smutek, ale agresję czuje [...] jak ktoś mnie zdenerwuje, to od razu walę. O trudnościach $\mathrm{z}$ opanowaniem agresji opowiadali także inni chłopcy: ja mam tak, że w złości musze w coś uderzyć. Wątek odwrócenia ról pojawia się także $\mathrm{w}$ rozmowie $\mathrm{z}$ chłopcem, który dokonał licznych kradzieży. Jego zdaniem osoby, które powinny odczuwać poczucie winy, to rodzicie, którzy pija, a dziecko trafia do domu dziecka. To dzieci są zatem ofiarami niewłaściwych działań dorosłych.

Poczucie winy jest uczuciem przykrym, ten, kto wyrządza krzywdę, odczuwa z tego powodu żal, smutek czy przygnębienie, a także złość na samego siebie. Badani nie łączyli tej emocji ze wstydem czy zażenowaniem, jak robią to niektórzy teoretycy emocji. Tylko jeden z rozmówców dostrzegł pozytywne aspekty tej emocji: poczucie winy jest na pewno czymś dobrym. Lepiej żałować złych rzeczy, niż być obojętnym, że się to zrobito. Poczucie winy dręczy, ale to świadczy o człowieku, że on wie, że on zrobit coś złego, na przykład. Nie jest mu to obojętne.

Inni badani wiązali poczucie winy $\mathrm{z}$ transgresją pewnych norm, przekroczeniem zakazów, a poczucie winy odczuwa się, gdy się coś źle zrobiło. Poczucie winy można zmniejszyć, podejmując jakieś działania na rzecz poszkodowanego, na przykład oddać skradzioną rzecz, przeprosić, przynieść kwiaty, odpokutować i starać się, aby więcej nie popetniać błędów takich samych. Intensywność tej emocji zależy od rodzaju przewinienia: im większa szkoda tym dłużej poczucie winy trwa.

Można zatem stwierdzić, że badani mają wiedzę ogólną na temat poczucia winy, sytuacji, w jakich się pojawia lub powinna pojawić oraz praktyk rehabilitujących. Jednakże gdy zostali poproszen o przywołanie sytuacji, w której przeżywali takie uczucie, najczęściej nie potrafili sobie takiej sytuacji przy pomnieć lub próbowali uchylić się od odpowiedzi na pytanie: nigdy $w$ życiu nie odczuwatem poczucia winy, nie przypominam sobie sytuacji. Niektórym udało się, po ponownej prośbie prowadzącego wywiad (Na pewno nigdy nie odczuwateś poczucia winy?), przywołać taką sytuację, innym natomiast próba ta się nie powiodła. Ci, którzy przypomnieli sobie zdarzenia ze swojego życia, w których odczuwali poczucie winy, opowiadali o sytuacjach z najbliższego kręgu rodzinnego: [n]o, ja nie wiem, no ja się tak nigdy nie czułem poczucia winy, no... Może czasami czułem, nie? Jak się z matka pokłóciłem, potem zadzwoniłem, zaprosiłem ja do restauracji, zjedliśmy obiad i ja powiedziałem: dobra mama, tam, nie ma co się kłócić. Potem czułem się lepiej, z uśmiechem wyszedłem. Inny chłopiec opowiadał o poczuciu winy, które związane jest z popełnieniem przez niego kradzieży: [b]yto tak. Byłem kiedyś w rodzinie zastępczej, to była taka daleka rodzina i ich okradtem. Na ciotkę byłem zdenerwowany i ja okradłem, znaczy jej męża, jego okradłem, a do niego nie miałem pretensji i źle zrobitem, bo powinienem ja okraść. Teraz, gdy gdzieś go spotykam $w$ mieście no i z nim rozmawiam, to się czuję dziwnie, źle, bo go niestusznie okradłem. Jak wynika z wypowiedzi, kwalifikacja moralna czynu nie wskazuje, że jest to działanie dewiacyjne per se, raczej jego słuszność czy niesłuszność wynika z osobistych 
relacji łączących jednostke $\mathrm{z}$ poszkodowanym. Inny badany opowiadał, że miał poczucie winy wobec swojej dziewczyny, ponieważ trafit tutaj, do ośrodka.

\section{Poczucie winy jako występ}

Jednakże badani zdawali sobie sprawę, że przeżywanie poczucia winy jest $\mathrm{w}$ pewnych sytuacjach społecznie aprobowane. Dlatego też $\mathrm{w}$ wielu rozmowach pojawił się wątek poczucia winy, który można nazwać powierzchniowym (Hochschild 2009). Nie jest to emocja, ale forma działania lub aktu illokucyjnego, który ma charakter pozorowania przeżycia (por. Szumska 2000). Ten aspekt ekspresji emocji często analizowany jest $\mathrm{w}$ teorii dramaturgicznej (por. Rosenberg 1990; Hochschild 2009). Pokazywanie, że przeżywa się poczucie winy po transgresji sytemu normatywnego ma wywołać u osoby poszkodowanej, a także publiczności uczucie sympatii, przebaczenia, jak i zmniejszyć dotkliwość ewentualnej kary. Dla publiczności obserwującej dewianta oznaki przeżywania tej emocji są dowodem na to, że nie jest on „,całkowicie zły", że jest nadzieja na jego naprawę i ponowne włącznie do społeczności (Darby, Schlenker 1989). Szczególnie dotyczy to młodocianych przestępców (Warling, Peterson-Badali 2003). Przeprosimy sa formą radzenia sobie $\mathrm{z}$ emocją, naprawienia obrazu własnej osoby $w$ oczach własnych i innych, a ich ekspresja jest formą przedstawienia, które aktor odgrywa przed jednostką (por. Goffman 2008), aby ponownie zintegrować się z grupą i zdjąć z siebie piętno. Może mieć formę gier (np. „przebacz i zapomnij") z analizy transakcyjnej (Lazarus 1991, por. Berne 2011), ale także manipulowania ekspresją ciała, szczególnie twarzy, prozodycznymi cechami mowy (Rosenberg 1990).
Strategiczna prezentacja poczucia winy podczas procesu sądowego pojawiła się $\mathrm{w}$ niemal każdym z wywiadów. Wychowankowie MOW opowiadali o podejmowanych działaniach powierzchniowych, odgrywaniu poczucia winy przed audytorium: udawałem, aby nie było gorzej, ale nie czułem poczucia winy. Pokazuje skruche, robie smutna mine, przepraszam i mówię, że sie to nie powtórzy; próbowatem się popłakać, ale nie umiem. Spuścitem wzrok i nic nie mówitem. Poczucie winy odgrywane było przed nauczycielami, wychowawcami, a przede wszystkim przed sądem: w sadzie zawsze trzeba pokazywac skruche, żeby sad wiedziat, że naprawde żatuję. Po co? Aby mieć mniejszy wyrok. Rozmówcy przyznali, że odgrywanie nie sprawiało im żadnych problemów, robienie smutnych min, rytualne wyznanie winy i okazanie żalu miało wyłącznie charakter instrumentalny. Zaznaczali jednocześnie, że nie są fałszywymi osobami, nie maja lewych uczuć, nie udaja, ale okoliczności nie pozwalały im na pokazanie, że poczucie winy jest im obce. Świadomość oczekiwań partnera interakcji i nadzieja na łagodne potraktowanie sprawiała, że badani zgadzali się na obsadzenie w roli skruszonego winowajcy.

\section{Neutralizacja poczucia winy}

Jednakże sytuacja taka nie jest komfortowa ze względu na niegodność wyrażanych emocji i braku ich odczuwania. W takich sytuacjach jednostki podejmują pracę emocjonalną, aby zredukować rozbieżności. W przypadku badanych możliwe są dwa scenariusze działań: wzbudzenie w sobie poczucia winy lub całkowite odrzucenie tej emocji na poziomie kognitywnym i behawioralnym. $\mathrm{W}$ drugim przypadku praca polegałaby na posługiwaniu się strategiami redukującymi odczuwanie poczucia winy poprzez pracę nad ciałem (np. kontrola eks- presji twarzy, redukcja napięcia mięśni, utrzymywanie wyprostowanej sylwetki) oraz reinterpretacjami sytuacji transgresji norm. Reinterpretacje te mogą być zobiektywizowane $\mathrm{w}$ formie wypowiedzi językowych, które nie tylko są ekspresją myśli czy odczuć jednostki, ale także formą pracy nad sobą. Sposób narracji, techniki argumentacyjne są częścią procesu interpretacyjnego, którego celem jest eliminacja poczucia winy lub niedopuszczenie do tego, aby się ono pojawiło.

W tej części analizy szczególnie przydatna jest teoria neutralizacji, sformułowana przez Greshama Sykesa i Davida Matzę (1979) oraz strategie dyskursywne, których celem jest odrzucenie lub zminimalizowanie odpowiedzialności za czyny (np. nominalizacje, pasywizacje, czasowniki modalne, konstrukcje hipotetyczne, przeczenia, zwroty typy "tylko", ,jedynie”, formy bezosobowe). Teoria neutralizacji zakłada, że przestępcy internalizują te same normy moralne co ogół społeczeństwa, jednakże w sytuacji popełnienia przestępstwa, normy te są neutralizowane (przed wykroczeniem lub po dokonaniu przestępstwa) w wyniku zabiegów racjonalizujących, co $\mathrm{w}$ rezultacie ułatwia złamanie nakazów i redukuje poczucie winy. Sykes i Matza (1979) wyróżnili następujące techniki neutralizacyjne: zaprzeczenie krzywdy, zaprzeczenie ofiary, potępienie potępiających, powołanie się na wyższe racje, opowiedzenie smutniej historii życia, odwołanie się do motywu samorealizacji (por. Hałas 2006). Lista tych strategii zastała poszerzona przez innych badaczy (np. Bandura 1977; Nelson, Lambert 2001): dodano między innymi otępienie emocjonalne, przedstawianie się $\mathrm{w}$ roli ofiary i soliptyczne definiowanie prawdy, łagodzace porównania, dehumanizację ofiary (zob. Byczkowska 2012). Badania pokazują także, że ten słownik motywów jest zróżnicowany w zależności od typu przestępstwa. Na przykład przestępczość gospodarcza (podatkowa, handlowa) częściej wiązała się z odwoływaniem się do powszechności praktyk, zaprzeczaniem krzywdzie, odwoływaniem się do konieczności przetrwania w biznesie; kradzieże natomiast - z odwoływaniem się do wyjątkowych okoliczności, obarczaniem winą innych osób (Benson 1985). Badane były także techniki stosowane przez przestępców, którzy przyswoili kody kultury przestępczej i neutralizowali odstąpienie od jego reguł (Topalli 2005).

Z przeprowadzonych wywiadów wynika, że badani stosowali zróżnicowane techniki neutralizacji, niekiedy kilka jednocześnie. Ważnym elementem tłumaczeń było odwołanie się do wyższych racji, takich jak pomoc rodzinie, obrona honoru bliskiej osoby czy zaprzeczenie ofiary (np. ukaranie winnych):

ja to robiłem z powodem. Miałem taką sprawę wykręcona, że mój brat młodszy chodzi do podstawówki i jakiś typek z IIIb zaczął go dusić i zbierać haracze, nie? A ja to na punkcie brata, rodziny to jestem agresywny, skocze w ogień za nimi i jak brat przyszedł do domu zapłakany, że mu ukradł telefon i pieniądze, to jak go dorwałem, to znalazł się na szczękówce chłopak. No i założyli mi sprawę za pobicie. Nie miałem poczucia winy, bo pomogłem bratu. [chłopiec, lat 15 , umieszony w MOW z powodu pobicia]

W innej wypowiedzi chłopiec zaprzecza krzywdzie ale nie eksponuje tej techniki neutralizacji, bowiem jego kompetencje byłyby podważone. Opowiadając swoją historię, był wyraźnie dumny ze swoich umiejętności, a z drugiej strony pokazywał, że został zmuszony do podjęcia wyzwania:

typek chciał się ze mną bić, ja na początku nie chciałem, a że miałem dobrą opinię w tych rzeczach, ogól- 
nie wszedzie, to powiedział niemiłe słowa o mojej mamie. A wszyscy wiedza, że jak ktoś powie niemiłe słowa o mojej mamie, to zabiję człowieka, no i skonczyło się tak, że wylądował w szpitalu. Ale nie dostał tak mocno, dostał kopa i strzała, wiem, jak uderzyć i był nieprzytomny. [chłopiec, lat 16, umieszony w MOW z powodu pobicia]

W dalszej części prezentował siebie jako człowieka przestrzegającego kodu bójek:

ktoś chciał się bić, a ponieważ u mnie na blokach ciągle się biją, to umiałem to i owo, kończyło się tak przeważnie, że koleś leżał i tyle, a ja odchodziłem. Mam zasadę, że jak ktoś leży, to go już nie kopię. [chłopiec, lat 16, umieszony w MOW z powodu pobicia]

Podobnie tłumaczył się inny badany, który obwiniał ofiary za niewłaściwe zachowanie wobec niego:

nie ponosi mnie tak, że nagle wybucham z siebie, ale są powody, jak ktoś mnie ubliży, to go przycisnę do ściany, popchnę go, a chyba, że mnie ktoś pierwszy uderzy, to się bronię. Ja nigdy pierwszy nie zaczynam, to nie mam poczucia winy, nie robię tak, że wychodzę na miasto i rozbijam kogoś, nie robię tak. Ja mam swoje zasady i się ich trzymam. [chłopiec, lat 17, umieszony w MOW z powodu pobicia]

Chłopiec, który umieszczony był w ośrodku z powodu pobić i kradzieży twierdził, że jedynie raz przeżywał poczucie winy:

uderzyłem chłopaka, wydawało mi się, że zasłużył, a tak naprawdę moja wyobraźnia zadziałała. Czasami można się pomylić, prawda? I uderzyłem go prawą ręką, tylko jeden cios wystarczył i chłopak musiał pojechać do szpitala z odklejeniem siatkówki. [chłopiec, lat 15, umieszony w MOW z powodu kradzieży z rozbojem]

Uważał, że pobił niewinnego człowieka, natomiast kradzieże usprawiedliwiał swoją trudną sytuacją materialną: jedni kradna dla sportu, a drudzy, żeby móc spokojnie spać, prawda? Bo niektórzy nie mają czegoś takiego, jak wsparcie rodziny czy choćby pieniądze na coś do picia i coś do jedzenia. Nie każdy tak ma. Ja myślałem, jakby tu zarobić pieniądze. [chłopiec, lat 15, umieszony w MOW z powodu kradzieży z rozbojem]

Z jego wypowiedzi wynika, że to zewnętrzne okoliczności zmusiły go do łamania prawa, a kradzież jest formą zarobkowania. Zewnętrzna atrybucja winy często przewijała się jako technika neutralizacji. Badani nie dostrzegali innego rozwiązania trudnej sytuacji:

ja nie biłem bez powodu i nie wiem, czy dałoby sie inaczej wyjść z tych sytuacji. Osoby, które ja pobiłem z pewnych powodów, nie czują się, moim zdaniem, pokrzywdzone, bo dobrze wiedziały, dlaczego to się stało. [chłopiec, lat 16, umieszony w MOW z powodu pobicia]

Winą obarczali rodziców, a także szkołę, pedagogów:

ja przyszedłem do gimnazjum z pozytywnym, takim kujońskim nastawieniem, ale skoro szkoła dla mnie tak, pedagog na mnie wszystko zwalała, wszystko było na mnie, mimo tego, że to nie ja, to po co mam się starać. Chodziło tylko o nazwisko, chciała się pozbyć mnie ze szkoły. To nie moja wina, to jest wina szkoły, przez szkołę stałem się taki, jaki jestem. [chłopiec, lat 15, umieszony w MOW z powodu pobicial

Chłopiec ten prezentuje się jako ofiara naznaczenia społecznego, która zmuszona została do przyjęcia roli „złego”. Chłopcy nie odczuwali wstydu wobec rodziny, znajomych, nie mieli poczucia że są w jakiś sposób naznaczeni czy wykluczeni. Przeciwnie, w ośrodku dbali o umacnianie swojego prestiżu, budowanego na ,złamanych paragrafach", podobnie jak to ma miejsce w subkulturze więziennej: ośrodek to jest takie coś, że jest tu za to szacunek, za takie wybryki.
Podsumowując, można stwierdzić, że badani posługiwali się przede wszystkim trzema technikami: zaprzeczeniem ofiary (poszkodowany sam jest sobie winien), zaprzeczeniem odpowiedzialności (chłopcy przedstawiali się jako ofiary sytemu lub określonych osób: nauczycieli, rodziców) oraz odwoływanie się do wyższych wartości (takich jak obrona młodszych, walka o honor rodziny). Pierwsza i trzecia technika były ze sobą ściśle powiązane: to ofiara łamała panujące normy i musiała być za to ukarana. Chłopcy zatem stawiali się w roli obrońców dobra.

Dokładniejsza analiza środków językowych może ujawnić, w jaki sposób badani konstruowali obraz siebie i swojej sytuacji, a także odsłonić pewną ukrytą warstwę znaczeń (por. Timor, Weiss 2008). $\mathrm{W}$ analizowanych wywiadach pojawiły się takie użycia mowy, które wyraźnie wskazują na próby przedstawienia swojej osoby w pozytywnym świetle i minimalizują, a może nawet eliminują, ewentualną możliwość wzbudzenia poczucia winy przez pracę nad emocjami. Są to przede wszystkim:

- omówienia, anafory, które pozwalają na unikanie nazywania czynów niedozwolonych, na przykład: ja to robitem z powodem, to była sprawa whrecona, chtopak wiedziat, dlaczego to się stato.

- unikanie sprawstwa przez stosowanie strony biernej, unikanie wiązania zdarzeń w ciągi przyczynowo-skutkowe: ktoś chciat się bić, kończyło się tak przeważnie, że koleś leżat i tyle, a ja odchodzitem. Typek chciał się ze mna bić, ja na poczatku nie chciałem.

- minimalizacje winy: przycisnę do ściany, popchne (o ciężkich pobiciach); ale nie dostał tak mocno; jakbym zrobit coś poważnego, czy coś, to bym poszedt do kryminatu; co ja tam robię? Krzyczę i tyle, czasem rzucam krzestem (o zadymach stadionowych); gdy nie bija nikogo bez powodu; nigdy nic strasznego nie zrobitem; ta osoba naprawde zastugiwata.

- normalizacje: u mnie na blokach ciagle sie bija.

- wskazywanie winnych, przedstawianie siebie w roli ofiary: A pedagog mnie tak nienawidzita. pedagog na mnie wszystko zwalała, chciała sie mnie pozbyć ze szkoty. Wszystko było na mnie, mimo tego, że to nie ja, to po co mam sie starać; rodzice powinn mieć poczucie winy wobec mnie; przez szkołe statem się taki, jaki jestem.

- odwoływanie się do poczucia sprawiedliwości słuchacza: Czasami można się pomylić, prawda? Jedni kradna dla sportu, a drudzy, żeby móc spokojnie spać, prawda? Bo niektórzy nie maja czegoś takiego, jak wsparcie rodziny.

- metafory podkreślające zaangażowanie w obronę skrzywdzonego członka rodziny: skocze wogień za nimi.

- czasowniki modalne wskazujące na konieczność działań: musiałem to zrobić

Zastosowane środki językowe wzmacniają zastosowane techniki neutralizacji, a manipulacja językiem sprawia, że odpowiedzialność za popełnione czyny zostaje zminimalizowana. Badani przedstawiali swoje działania jako nieintencjonalne, a samych siebie jako ofiary poszkodowanych. W opowiadaniach unikano opisu przeżyć ofiary, skupiając się przede wszystkim na przyczynach działań bardzo oględnie przedstawiono także skutki tych działań. Opisy wydarzeń są pozbawione detali, epitetów, sytuacje przedstawiane są w sposób bardzo ogólny i szkicowy, tak aby słuchacz otrzymał jak najmniej informacji o przebiegu zdarzenia. 


\section{Podsumowanie}

Trudno jest jednoznacznie rozstrzygnąć, czy faktycznie badani odczuwają poczucie winy, czy jest ono wyparte do poziomu podświadomości, jak sugerują niektórzy badacze (np. Turner 2006). Wyniki badań przeprowadzonych za pomocą testów psychologicznych wskazują, że przestępcy nie przeżywają poczucia winy (Meyer i in. 2002), co nie oznacza, że każdy z nich ma zaburzenia socjopatyczne (szacuje się, że 3-4\% ogółu społeczeństwa dotkniętych jest psychopatią i socjopatią [por. Mealy 1995]). Jednakże przedmiotem omawianych powyżej badań byli młodociani wykazujący się stosunkowo niskim poziomem zdemoralizowania, $\mathrm{w}$ przeciwnym razie umieszczeni byliby w zakładach poprawczych. Należy wziąć pod uwagę fakt, że poczucie winy jest emocją na tyle przykrą, że osoby ją przeżywające niechętnie ją ujawniają w narracjach (Rimé 2009).

Przyjmując perspektywę konstruktywizmu, istotne było, jak badani o poczuciu winy mówią i jakie funkcje pełni ich retoryka. Można zauważyć, że z jednej strony retoryka pełni funkcje perswazyjne i opowieści o odczuwaniu winy różnią się z zależności od tego, czy są skierowane do przedstawicieli instytucji resocjalizacyjnych czy do badacza. $\mathrm{W}$ pierwszym przypadku opowiadanie o emocjach jest spektaklem ukorzenia i próbą restytucji przez symboliczne wyrażenie skruchy i publiczne przeproszenie. $\mathrm{W}$ drugim zaś badacz jest publicznością, którą przekonuje się o własnej niewinności lub przynajmniej minimalizuje winę za pomocą technik neutralizacyjnych i środków językowych. Jednakże nie chodzi tu tylko o perswazję, ale opowieść o poczuciu winy, manipulowanie tym uczuciem jest częścią pracy nad tożsamością. W sytuacji wywiadu badani symbolicznie rekonstruowali przeszłe wydarzenia, nadając im znaczenia, które istotne są dla ich teraźniejszej tożsamości. Podobnie jak na sali sądowej okazywanie winy miało chronić pozytywny wizerunek badanego (,odczuwam winę, więc nie jestem zły"), w sytuacji wywiadu całkowite zaprzeczenie odczuwaniu te emocji pełni taką samą funkcję (,nie odczuwam winy, bo nie zrobiłem nic złego"). Uczestniczenie w wywiadzie było dla nich okazją do podtrzymania pozytywnej tożsamości.

Poczucie winy jest emocją, na którą w instytucjach resocjalizacyjnych nie ma przyzwolenia, dlatego też stosuje się różnego typu strategie retoryczne, które kontrolują i zapobiegaja pojawieniu się tej emocji. Na ile skuteczna może być w tej sytuacj resocjalizacja? W jaki sposób skłonić osoby niedostosowane do akceptacji systemu normatywnego? Anthony Burgess w Mechanicznej pomarańczy (1991) opowiada o terapii behawioralnej zastosowanej wobec wyjątkowo zdeprawowanego Alexa, pozornie skutecznej, ale pozbawiającej go możliwości wyboru dobra. Co mogłoby powstrzymać badanych chłopców przed powtórnym łamaniem prawa? Być może manipulacja strachem przed karą, zakładem poprawczym lub więzieniem, a także chłodna kalkulacja, że popełnianie wykroczeń po prostu się nie opłaca:

poczułem tą karę, dwa ośrodki. Ośrodek zabier czas, tak naprawdę, siedzimy tutaj, gdy moglibyśmy siedzieć na wolności, robić różne rzeczy, których tu nie możemy, akurat najlepsze lata. Ja bym sobie teraz z chęcią pochodził do normalnej szkoły, gdzie sa dziewczyny, na przykład. [chłopiec, lat 17, umieszony w MOW z powodu chuligaństwa]

Jednakże nie można wykluczyć, że wprowadzenie w ramach działań resocjalizacyjnych „pracy nad emocjami" nie na poziomie działań powierzch- niowych, ale głębokich warstw jaźni, zaowocuje rozbudzeniem zdolności do odczuwania empatii, zaangażowaniem emocjonalnej sfery osobowości, aby poczucie winy, a nie strach przed karą, było głównym czynnikiem powstrzymującym przed popełnieniem czynów zabronionych. Badania kryminologów wykazują, że przeżywanie poczucia winy jest jednym z czynników hamujących trajektorię przestępczości (Mayer i in. 2002; Hosser, Windzio, Greve 2008). Być może zatem działania resocjalizujące powinny skupić się na pracy nad emocjami, terapeutycznym wzbudzaniu poczucia winy i w ten sposób zmianie tożsamości osób dokonujących przestępstw, aby zapobiec zjawisku etykietyzacji (por. Thoits 1996). Pomocne mogą być w tym ćwiczenia jogiczne, kontakt z ludźmi i zwierzętami potrzebującymi pomocy orz specjalne programy terapeutyczne (np. ICVC)(Jaworska 2010; Jackson i in. 2011).

\section{Podziękowania}

Serdecznie dziękuję Panu Uri Timorowi z Uniwersytetu Bar-Ilan za udostępnienie swojego artykułu Sociolinguistic and Psycholinguistic Indications of Behavior Disorders. Analysis of a Prisoner's Discourse, opublikowanego w 2008 roku w „International Journal of Offender Therapy and Comparative Criminology", vol. 52, no. 1, s. 112-126 (współautor Joshua M. Weiss).

\section{Bibliografia}

Bandura Albert (1977) Social Learning Theory. Englewood Cliffs, London: Prentice-Hall.

Baumeister Roy. F., Stillwell Arlene M., Heatherton Todd F. (1994) Guilt: An Interpersonal Approach. „Psychological Bulletin", vol. 115, no. 2, s. 243-267.

Baumeister Roy F., Bushman Brad J. (2008) Social Psychology and Human Nature. Belmont: Thomson Higher Education.

Benson Michael L. (1985) Denying the Gulity Mind. Accounting for Involvement in a White-Collar Crime. "Criminology“, vol. 23, no. 4, s. 583-607.

Berne Eric (2011) W co graja ludzie. Psychologia stosunków międzyludzkich. Przełożył Paweł Izdebski. Warszawa: Wydawnictwo Naukowe PWN.
Bernstein Basil (1971) Class, Codes and Control. London: Routledge.

Biaggio Angela M. (1969) Internalized versus externalized guilt: A cross-cultural study. „The Journal of Social Psychology", vol. 78, no. 1, s. 147-149.

Blau Peter M. (1964) Exchange and Power in Social Life. New York: John Wiley \& Sons.

Bourion Christian (2005) Emotional Logic and Decision Making. The Interface between Professional Upheaval and Personal Evolution. New York: Palgrave Macmillan.

Braithwaithe John (1989) Crime, Shame and Integration. Cambridge: Cambridge University Press.

Buchała Kazimierz, Zoll Andrzej (1998) Kodeks karny. Czesśc ogólna. Kraków: Kantor Wydawniczy Zakamycze. 
Butler Judith (1997) The Psychic life of Power: Theories in Subjection. Stanford: Stanford University Press.

Burgess Anthony (1991) Mechaniczna pomarańcza. Przełożył Robert Stiller. Warszawa: WEMA.

Byczkowska Dominika (2012) Techniki neutralizacji [w:] Krzysztof T. Konecki, Piotr Chomczyński, red., Stownik socjologii jakościowej. Warszawa: Difin, s. 278-280.

Caplovitz Barrett K. (1995) A functionalist approach to shame and guilt [w:] June P. Tangney, Kurt W. Fischer, eds., The psychology of shame, guilt, embarrassment and pride. New York: Guilford Press, s. 25-63.

Clark Margaret S., Fitness Julie, Brissette Ian (2003) Understanding People's Perceptions of Relationships Is Crucial to Understanding their Emotional Lives [w:] Garth J. O. Fletcher, Margaret S. Clark, eds., Blackwell Handbook of Social Psychology: Interpersonal Processes. Malden: Blackwell, s. 253-278.

Cohen Taya R., Panter Abigail T., Turan Nazli (2012) Guilt proneness and moral character. "Current Directions in Psychological Science”, vol. 21, no. 5, s. 355-359.

Cooley Charles H. (1964) Human Nature and the Social Order. New York: Schocken Books.

Darby Bruce W., Schlenker Barry R. (1989) Children's reactions to transgressions: Effects of the actor's apology, reputation, and remorse. "British Journal of Social Psychology", vol. 28 , no. 4 , s. 353-364.

Douglas Mary (2004) Symbole naturalne. Przełożyła Ewa Dżurak. Kraków: Wydawnictwo Uniwersytetu Jagiellońskiego.

Durkheim Émile (2011) Samobójstwo. Przełożył Krzysztof Wakar. Warszawa: Oficyna Naukowa.

Emde Robert N. (1984) Levels of Meaning for Infant Emotions: A biosocial view [w:] Klaus R. Scherer, Paul Ekman, eds., Approaches to Emotion. Hillsdale: Lawrence Erlbaum Associates, s. 1-37.

Erikson Erik (2000) Dzieciństwo i społeczeństwo. Przełożył Przemysław Hejmej. Poznań: Dom Wydawniczy "Rebis".
Ferguson Tamara J., Stegge Hedy, Damhuis Ilse (1991) Children's understanding of guilt and shame. "Child Development", vol. 62, no. 4, s. 827-839.

Fischer Agneta H., van Kleef Gerben A. (2010) Where Have Al the People Gone? A Plea for Including Social Interaction in Emotion Research. "Emotion Review", vol. 2, no. 3, s. 208-212.

Greer Kimberly (2002) Walking an Emotional Tightrope: Managing Emotions in a Women's Prison. „Symbolic Interaction", vol. 25, no. 1, s. 117-139.

Gilbert Margaret (2002) Collective Guilt and Collective Guilt Feelings. „Journal of Ethics", vol. 6, no. 2 s. 115-143.

Goffman Erving (2008) Człowiek w teatrze życia codziennego. Przełożyli Helena Datner-Śpiewak i Pawe Spiewak. Warszawa: Wydawnictwo Aletheia.

Halberstadt Amy G., Lozada Fantasy T. (2011) Emotio Development in Infancy through the Lens of Culture. "Emotion Review", vol. 3, no. 2, s. 158-168

Hałas Elżbieta (2006) Interakcjonizm symboliczny. społeczny kontekst znaczeń. Warszawa: Wydawnictwo Naukowe PWN.

Hegtvedt Karen A. (1990) The Effects of Relationship Structure on Emotional Reactions to Inequity. "Social Psychology Quarterly“, vol. 53, no. 3, s. 214-228.

Hochschild Arlie R. (2009) Zarzadzanie emocjami. Komercjalizacja ludzkich uczuć. Przełożył Jacek Konieczny. Warszawa: Wydawnictwo Naukowe PWN.

Hoffman Martin L. (2000) Empathy and Moral Development. Implications for Caring and Justice. Cambridge, New York: Cambridge University Press.

Homans George C. (1961) Social Behaviors: Its Elementary Forms. New York: Harcourt Brace \& World.

Hosser Daniela, Windzio Michael, Greve Werner (2008) Guilt and Shame as Predictors of Recidivism. A Longitudinal Study With Young Prisoners. „Criminal Justice and Behavior", vol. 35, no. 1, s. 138-152.

Jackson Arrick L. i in. (2011) An Examination of Guilt, Shame, Empathy and Blaming Among a Sample of Incarcer- ated Male and Female Offenders, Southwest Journal of Criminal Justice", vol. 8, no. 1, s. 4-29.

Jacyno Małgorzata (2007) Kultura indywidualizmu. Warszawa: Wydawnictwo Naukowe PWN.

Jaworska Anetta (2010) Holistyczne perspektywy pracy ze skazanymi niewykazujacymi zaburzeń osobowości. „Probacja", t. 3-4, s. 78-91.

Kelers Jochen (2010) Emotions and Narrative Analysis: A Methodological Approach. "Journal for the Theory of Social Behaviour", vol. 41, no. 2, s. 182-201.

Kemper Theodore D. (1987) How Many Emotions Are There? Wedding the Social and the Autonomic Components. "American Journal of Sociology", vol. 93, no. 2 , s. 263-289.

Kępiński Antoni (1979) Melancholia. Warszawa: PZWL.

---- (1992) Schizofrenia. Warszawa: Sagittarius.

Kristjánsson Kristián (2010) The Self and Its Emotions. Cambridge: Cambridge University Press.

Laird James (2007) Feelings. The Perception of Self. Oxford: Oxford University Press.

Lazarus Richard S. (1991) Emotion and Adaptation. Oxford: Oxford University Press.

Lewis Helen B. (1971) Shame and guilt in neurosis. New York: International Universities Press.

Lewis Michael, Haviland-Jones Jeannette M., eds., (2008) Handbook of Emotions. New York: The Guilford Press.

Manstead Antony S. R. (2010) Social Psychology of Emotion [w:] Roy F. Baumeister, Eli J. Finkel, eds., Advanced Social Psychology: the State of the Science. Oxford: Oxford University Press, s. 101-137.

Mariański Janusz (1989) Wprowadzenie do socjologii moralności. Lublin: Redakcja Wydawnictw KUL.

---- (1990) Moralność w procesie przemian. Szkice socjologiczne. Warszawa: Instytut Wydawniczy PAX.

Mealy Linda (1995) The Sociobiology of Sociopathy: An Integrated Evolutionary Model. „Behavioral and Brain Sciences", vol. 18, no. 3, s. 523-599.
Meyer Patric i in. (2002) Criminogenic Beliefs and Assumptions Scale (CBAS). Fairfax: George Mason University.

Nelson E. D., Lambert R. D. (2001) Stick, Stones and Semantics: The Izory Tower Bully's Vocabulary of Motives. "Qualitative Sociology", vol. 24, no. 1, s. 83-106.

Pawlik Wojciech (2007) Grzech. Studium z socjologi moralności. Kraków: NOMOS.

Plutchik Robert (1991) The Emotions: Facts, Theories, and a New Model. Lanham: University Press of America.

Prinz Jesse J. (2005) Passionate Thoughts The Emotiona Embodiment of Moral Concepts [w:] Diane Pecher, Rolf A. Zwaan, eds., Grounding Cognition The Role of Perception and Action in Memory, Language, and Thinking. Cambridge: Cambridge University Press, s. 93-114.

Ranschburg Jenö (1980) Lęk, gniew, agresja. Przełożyła Magdalena Schweinitz-Kulisiewicz. Warszawa: Wydawnictwo Szkolne i Pedagogiczne.

Ricoeur Paul (1991) Podług nadziei: odczyty, szkice, studia. Przełożył Stanisław Cichowicz i in. Warszawa: Pax.

Rimé Bernard (2009) Emotion Elicits the Social Sharing of Emotion: Theory and Empirical Review. „Emotion Review”, vol. 1, no. 1, s. 60-85.

Rosenberg Morris (1990) Reflexivity and Emotions. „Social Psychology Quarterly“, vol. 53, no. 1, s. 3-12.

Rozporzadzenie Ministra Edukacji Narodowej z dnia 12 maja 2011 roku w sprawie rodzajów i szczegótowych zasad działania placówek publicznych, warunków pobytu dzieci i młodzieży w tych placówkach oraz wysokości i zasad odpłatności wnoszonej przez rodziców za pobyt ich dzieci w tych placówkach. Dziennik Ustaw z 30 maja $2011 \mathrm{nr}$ 109, poz. 631.

Sheikh Sana, Janoff-Bulman Ronnie (2010) The "should" and "should nots" of moral emotions: a self-regulatory perspective on shame and guilt. „Personality and Social Psychology Bulletin", vol. 36, no. 2, s. 213-224.

Shiota Michelle N., Kalat James W. (2007) Emotion. Belmont: Wadsworth. 
Shott Susan (1979) Emotion and Social Life: A Symbolic Integrationist Analysis. „American Journal of Sociology", vol. 84, no. 6, s. 1317-1334.

Shweder Richard A. i in. (1997) The "Big Three" of Morality (Autonomy, Community, Divinity), and the "Big Three" Explanations of Suffering [w:] Allan Brandt, Paul Rozin, eds., Morality and Health. New York: Routledge, s. 119-169.

Singer Elly, Doornenbal Jeannette (2006) Learning Morality in Peer Conflict: A study of schoolchildren's narratives about being betrayed by a friend. "Childhood", vol. 13, no. 2 , s. $225-245$

Stownik języka polskiego PWN [dostęp 10.05.2012 r.]. Dostępny w Internecie 〈http://usjp.pwn.pl〉.

Solomon Robert C. (2007) True to Our Feelings What Our Emotions Are Really Telling Us. Oxford: Oxford University Press.

Summers-Effler Erika (2004) Defensive Strategies: The Formation and Social Implications of Patterned Self-Destructive Behavior. „Advances in Group Processes”, vol. 21, s. 309-326.

Stets Jan E. (2006) Emotions and Sentiments [w:] John Delamater, ed., Handbook of Social Psychology. New York: Springer, s. 309-335.

Stets Jan E., Carter Michael J. (2012) A Theory of the Self for the Sociology of Morality. „American Sociological Review", vol. 77, no. 1, s. 120-140.

Sykes Gresham, Matza David M. (1979) Techniques of Neutralization: A theory of Deliquency [w:] H. Robboy, S. Greenblatt, C. Clark, eds., Social Interaction. Introductory Readings in Sociology. New York: St. Martin Press, s. $497-504$.

Szumska Dorota (2000) O emocjach bez emocji [w:] A. Iwona Nowakowska-Kempna, Anna Dąbrowska, Janusz Anusiewicz, red., Jezzk a kultura, t. 14. Wrocław: Wydawnictwo Uniwersytetu Wrocławskiego, s. 199-208.

Tangney June P. (1991) Moral Affect: the Good, the Bad, and the Ugly. „Journal of Personality and Social Psychology", vol. 61 , no. 4, s. 598-607.
Tangney June P., Dearing Ronda L. (2002) Shame and Guilt. New York: Guilford Press.

Tangney June P., Stuewig Jeff, Mashek Debra J. (2007) Moral Emotions and Moral Behavior. "Annual Review of Psychology", vol. 58, no. 1, s. 345-372.

Tangney June P. i in. (1998) Are Shame and Guilt Related to Distinct Self-discrepancies? A test of Higgins's (1987) hypothesis. "Journal of Personality and Social Psychology", vol. 75 , no. 1 , s. $256-268$.

TenHouten Warren D. (2007) A General Theory of Emotion and Social Life. London, New York: Routledge.

Teroni Fabrice, Deonna Julien A. (2008) Differentiating Shame from Guilt. "Consciousness and Cognition", vol. 17, no. 4, s. 725-740.

Thoits Peggy A. (1996) Managing the Emotions of Others. „Symbolic Interaction“, vol. 19, no. 2, s. 85-109.

Tillmann Klaus-Jurgen (2005) Teorie socjalizacji: społeczność, instytucja, upodmiotowienie. Przełożyli Grzegorz Bluszcz i Bartek Miracki. Warszawa: Wydawnictwo Naukowe PWN.

Timor Uri, Weiss Joshua M. (2008) Sociolinguistic and Psycholinguistic Indications of Behavior Disorders. Analysi of a Prisoner's Discourse. „International Journal of Offender Therapy and Comparative Criminology", vol. 52, no. 1, s. 112-126.

Topalli Volkan (2005) When Being Good Is Bad: An Expansion of Neutralization Theory. "Criminology", vol. 43, no. 3 , s. $797-836$

----- (2006) The Seductive Nature of Autotelic Crime: How Neutralization Theory Serves as a Boundary Condition for Understanding Hardcore Street Offending. "Sociological Inquiry", vol. 76, no. 4, s. 475-501.

Turner Jonathan H. (2002) Face to Face: Toward a Sociological Theory of Interpersonal Behavior. Stanford: Stanford University Press.

Turner Jonathan H. (2006) Psychoanalytic Sociological Theories and Emotion [w:] Jan E. Stets, Jonathan H. Turner, eds, Handbook of the Sociology of Emotion. New York: Springer, s. 276-294.
Turner Jonathan H., Stets Jan E. (2009) Socjologia emocji. Przełożyła Marta Bucholc. Warszawa: Wydawnictwo Naukowe PWN.

Ustawa o postępowaniu w sprawach nieletnich $z$ dnia 26 października 1982. Dziennik Ustaw z 2010 r., nr 33, poz. 178.

Wallbott Harald, Scherer Klaus (1995) Cultural Determinants in Experiencing Shame and Guilt [w:] June P. Tangney, Kurt W. Fischer, eds., Self-conscious Emotions: The psychology of Shame, Guilt, Embarrassment, and Pride. New York: Guilford Press, s. 465-487.
Warling Diane, Peterson-Badali Michele (2003) The Verdict on Jury Trials for Juveniles: The Effects of Defendant's Age on Trial Outcomes. „Behavioral Sciences and the Law”, vol. 21, no. 1, s. 63-82.

Weber Max (1995) Szkice z socjologii religii. Przełożyli Jerzy Prokopiuk i Henryk Wandowski. Warszawa: Książka i Wiedza.

Wierzbicka Anna (1999) Emotions Across Languages and Cultures: Diversity and Universals. Cambridge: Cambridge University Press. 